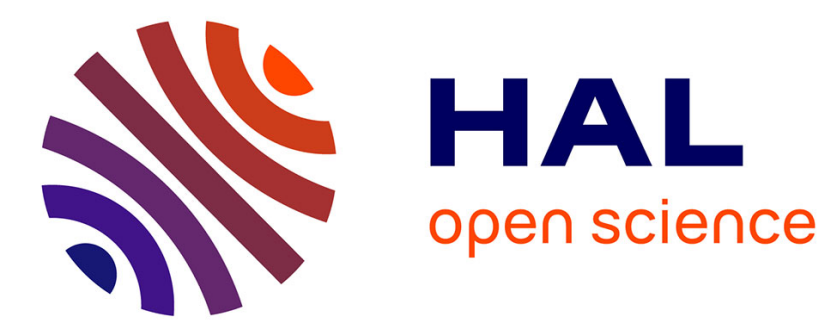

\title{
GeTe2O6, a germanium tellurate(IV) with an open framework
}

Nefla Jennene Boukharrata, Philippe Thomas, Jean-Paul Laval

\section{To cite this version:}

Nefla Jennene Boukharrata, Philippe Thomas, Jean-Paul Laval. GeTe2O6, a germanium tellurate(IV) with an open framework. Acta Crystallographica Section C : Crystal Structure Communications [19682013], 2009, C65 (5), pp.i23-i26. 10.1107/S0108270109010488 . hal-00389223

\section{HAL Id: hal-00389223 https://hal.science/hal-00389223}

Submitted on 30 Nov 2017

HAL is a multi-disciplinary open access archive for the deposit and dissemination of scientific research documents, whether they are published or not. The documents may come from teaching and research institutions in France or abroad, or from public or private research centers.
L'archive ouverte pluridisciplinaire HAL, est destinée au dépôt et à la diffusion de documents scientifiques de niveau recherche, publiés ou non, émanant des établissements d'enseignement et de recherche français ou étrangers, des laboratoires publics ou privés. 
Acta Crystallographica Section C

\section{Crystal Structure}

Communications

ISSN 0108-2701

\section{$\mathrm{GeTe}_{2} \mathrm{O}_{6}$, a germanium tellurate(IV) with an open framework}

\author{
Nefla Jennene Boukharrata, Philippe Thomas and \\ Jean-Paul Laval*
}

Science des Procédés Céramiques et de Traitements de Surface, UMR-CNRS 6638, Université de Limoges, Faculté des Sciences et Techniques, 123 Avenue A. Thomas, Limoges 87060, France

Correspondence e-mail: jean-paul.laval@unilim.fr

Received 5 February 2009

Accepted 21 March 2009

Online 10 April 2009

The structure of an already evidenced but still uncharacterized $\mathrm{GeTe}_{2} \mathrm{O}_{6}$ phase consists of isolated $\mathrm{GeO}_{6}$ octahedra connected via isolated $\mathrm{TeO}_{3}$ units. The germanium cations occupy a site with $\overline{1}$ symmetry. The $\mathrm{Te}$ and $\mathrm{O}$ atoms are in general positions of the $P 2_{1} / n$ space group. This structure corresponds to a new type of tetravalent tellurate and is different from other $A B_{2} X_{6}$ structures in which the $B$ cation presents a stereochemically active electronic lone pair. It derives from the pseudohexagonal $\mathrm{MI}_{2} \mathrm{O}_{6}(M=\mathrm{Mg}, \mathrm{Mn}$, Co and $\mathrm{Fe})$ type by a strong monoclinic distortion caused by the much smaller size of $\mathrm{Ge}^{4+}$ compared with the divalent $M$ cations.

\section{Comment}

Germanium oxide has been used as a building element to form a number of open frameworks with novel topologies. The structure of the germanate framework can be formed by $\mathrm{GeO}_{4}$ (tetrahedra), $\mathrm{GeO}_{6}$ (octahedra) and sometimes $\mathrm{GeO}_{5}$ (square pyramid or trigonal bipyramid) polyhedra (Liu et al., 2008). Meanwhile, our laboratory has systematically developed the investigation of tellurium(IV) compounds for their potential nonlinear optical properties (Laval et al., 2008). We have attempted to combine the building capability of $\mathrm{Ge}^{\mathrm{IV}}$ oxide with $\mathrm{Te}^{\mathrm{IV}}$ oxide in an effort to obtain novel germanium oxyfluorotellurates. In this paper, we report the structure of the oxide $\mathrm{GeTe}_{2} \mathrm{O}_{6}$, which was inadvertently obtained in one of our reactions. The powder X-ray diffraction pattern has been reported (PDF No. 00-051-0288; Gospodinov, 1999); however, the pattern calculated from the present crystal structure differs from the reference pattern, suggesting that the PDF file does not correspond to a pure phase or to the same polymorph. Bond valence calculations (Brown, 1981) confirm that the studied crystal corresponds to an oxide and not to an oxyfluoride as expected (Table 2).

In this structure, the Ge atom is sixfold coordinated, occupying the center of an almost regular octahedron (Fig. 1). The $\mathrm{Ge}-\mathrm{O}$ distances are essentially the same within experimental uncertainty (Table 1) and are typical for germanates (Monge et al., 2000; Cascales et al., 1998; Xu et al., 2004).

The configuration of the Te atom is the same as that in $M \mathrm{TeO}_{3} \mathrm{~F}(M=\mathrm{Fe}, \mathrm{Ga}$ and $\mathrm{Cr}$; Laval et al., 2008), i.e. strongly bonded to three $\mathrm{O}$ atoms $(\mathrm{O} 1, \mathrm{O} 2$ and $\mathrm{O} 3$; Table 1$)$ at the center of a tetrahedron whose fourth corner corresponds to the direction of the stereochemically active lone pair $E$ (Fig. 2). Three additional weak $\mathrm{Te}-\mathrm{O}$ bonds can be added to the coordination environment of the Te atom. In that case, the corresponding polyhedron can be roughly described as a distorted octahedron. The lone pair $E$ points towards the face formed by atoms $\mathrm{O} 1^{\mathrm{i}}, \mathrm{O} 1^{\mathrm{ii}}$ and $\mathrm{O}^{\mathrm{iii}}$ [symmetry codes: (i) $-x+1,-y,-z+1$; (ii) $x+\frac{1}{2},-y+\frac{1}{2}, z+\frac{1}{2}$; (iii) $-x+\frac{1}{2}, y-\frac{1}{2}$, $\left.-z+\frac{3}{2}\right]$

The $\mathrm{GeTe}_{2} \mathrm{O}_{6}$ structure is based on the association, by corner-sharing, of $\mathrm{GeO}_{6}$ octahedra and $\mathrm{TeO}_{3}$ trigonal pyramids. Each Te atom is bonded to three different $\mathrm{Ge}$ atoms via oxygen vertices, and conversely each $\mathrm{GeO}_{6}$ octahedron is linked via six $\mathrm{TeO}_{3}$ bridges to ten other $\mathrm{GeO}_{6}$ octahedra. Projections on to the three main planes of the almost orthorhombic structure (Fig. 3) show that the $\mathrm{GeO}_{6}$ octahedra are tilted along the [010] direction and form layers perpendicular to [001], each one alternating with a wavy layer of tellurium. The three-dimensional framework of $\mathrm{Te}$ and $\mathrm{Ge}$ cations derives from a hexagonal packing, but with great distortion $[a / b=0.749$ for the monoclinic, near-orthorhombic $(\beta=$ $\left.91.66^{\circ}\right)$, unit cell, instead of $a / b=3 / 2^{1 / 2}$ for the orthorhombic supercell derived from a hexagonal unit cell].

If the weak $\mathrm{Te}-\mathrm{O}$ bonds are considered, $\mathrm{Te}_{4} \mathrm{O}_{20}$ units are formed. These units are connected via $\mathrm{O} 1$ vertices to form

Figure 1

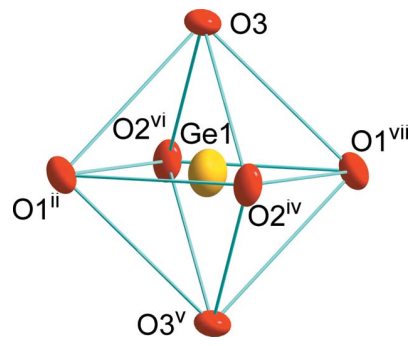

The coordination polyhedron of $\mathrm{Ge} 1$ in the $\mathrm{GeTe}_{2} \mathrm{O}_{6}$ structure. [Symmetry codes: (ii) $x+\frac{1}{2},-y+\frac{1}{2}, z+\frac{1}{2}$; (iv) $x-\frac{1}{2},-y+\frac{1}{2}, z+\frac{1}{2}$; (v) $-x+1,-y+1,-z+2 ;$ (vi) $-x+\frac{3}{2}, y+\frac{1}{2},-z+\frac{3}{2}$; (vii) $-x+\frac{1}{2}, y+\frac{1}{2},-z+\frac{3}{2}$.]

Figure 2

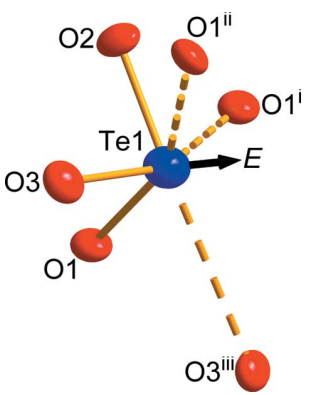

The anionic polyhedron around the $\mathrm{Te}^{4+}$ cation in the $\mathrm{GeTe}_{2} \mathrm{O}_{6}$ structure. The arrow indicates the direction in which the lone pair $E$ points. Broken lines represent weak $\mathrm{Te} 1-\mathrm{O}$ bonds. [Symmetry codes: (i) $-x+1,-y$, $-z+1$; (ii) $x+\frac{1}{2},-y+\frac{1}{2}, z+\frac{1}{2}$; (iii) $-x+\frac{1}{2}, y-\frac{1}{2},-z+\frac{3}{2}$.] 
infinite rows along [010] with cavities of irregular cross section (Fig. $4 a$ ). The $\mathrm{GeO}_{6}$ octahedra ensure the connection of these rows (Fig. 4b).

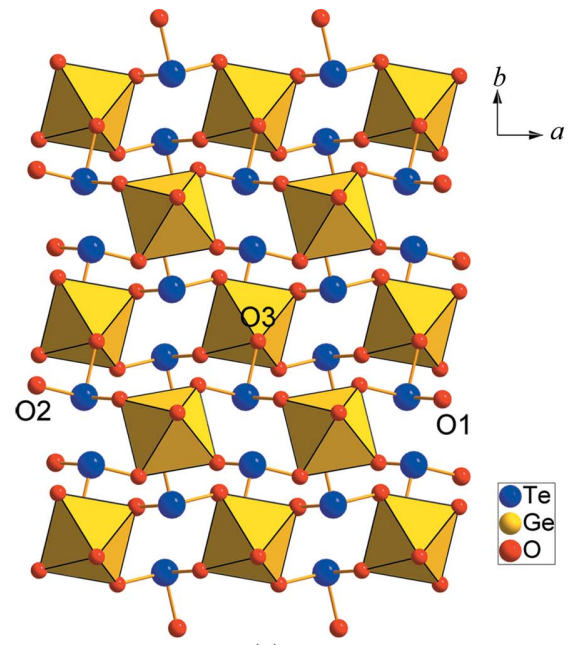

(a)

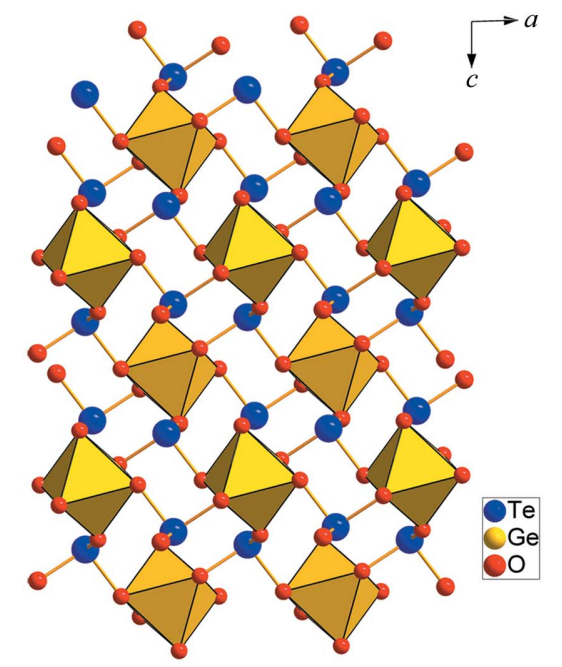

(b)

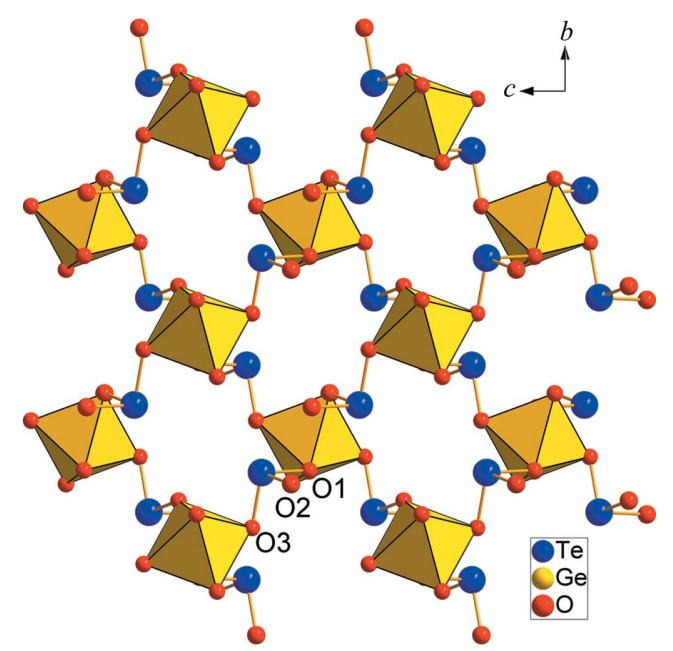

(c)

Figure 3

Projections on to $(a)$ the $x y,(b)$ the $x z$ and $(c)$ the $y z$ planes, showing the $\mathrm{GeO}_{6}$ octahedra and their connection via $\mathrm{TeO}_{3}$ polyhedra.
The $M_{x} \mathrm{Te}_{y} \mathrm{O}_{z}$ tellurates(IV) present many $M / \mathrm{Te}$ compositions, from 5/1 $\left(\mathrm{Mo}_{5} \mathrm{TeO}_{16}\right)$ to $1 / 6\left(\mathrm{ZnTe}_{6} \mathrm{O}_{13}\right)$. However, the main $M /$ Te ratios for di-, tri-, tetra-, penta- or hexavalent metal oxides are 1/1 [e.g. $\left.\mathrm{CoTeO}_{3}, \mathrm{VTeO}_{4}, \mathrm{Ta}_{2}\left(\mathrm{~V}_{2}\right) \mathrm{Te}_{2} \mathrm{O}_{9}\right], 3 / 2[$ e.g. $\mathrm{Ni}_{2} \mathrm{Te}_{3} \mathrm{O}_{8}, \mathrm{Fe}_{2}$ (or $\left.\mathrm{In}_{2}\right) \mathrm{Te}_{3} \mathrm{O}_{9}, \mathrm{Nb}_{2} \mathrm{Te}_{3} \mathrm{O}_{11}$ ], 1/2 [e.g. $\mathrm{MgTe}_{2} \mathrm{O}_{5}$, $\mathrm{Cr}_{2}$ (or $\left.\mathrm{Ln}_{2}\right) \mathrm{Te}_{4} \mathrm{O}_{11}$, Th(or $\mathrm{Ce}$ or $\left.\mathrm{Pu}\right) \mathrm{Te}_{2} \mathrm{O}_{6}, \mathrm{Nb}_{2} \mathrm{Te}_{4} \mathrm{O}_{13}$, $\mathrm{MoTe}_{2} \mathrm{O}_{7}$ ], 5/2 [e.g. $\mathrm{Sc}_{2}\left(\right.$ or $\left.\mathrm{Lu}_{2}\right) \mathrm{Te}_{5} \mathrm{O}_{13}$ ], 1/3 [e.g. $\mathrm{Zr}$ (or $\mathrm{Sn}$ or $\left.\mathrm{Hf}) \mathrm{Te}_{3} \mathrm{O}_{8}\right], 1 / 5\left(\right.$ e.g. $\left.\mathrm{PbTe}_{5} \mathrm{O}_{11}\right)$ and $1 / 6\left(\right.$ e.g. $\left.\mathrm{ZnTe}_{6} \mathrm{O}_{13}\right)(\mathrm{FIZ} /$ NIST, 2008).

These phases present a very rich crystallochemistry, with structures generally consisting of more or less complex associations (groups, chains or layers) of $\mathrm{MO}_{6}$ octahedra and of $\mathrm{TeO}_{3}$ or $\mathrm{TeO}_{4}$ polyhedra. $\mathrm{GeTe}_{2} \mathrm{O}_{6}$ is a new structure type for tetravalent tellurates and is simpler than most of the phases noted above. In fact, few tellurates(IV) contain isolated $M_{6}$

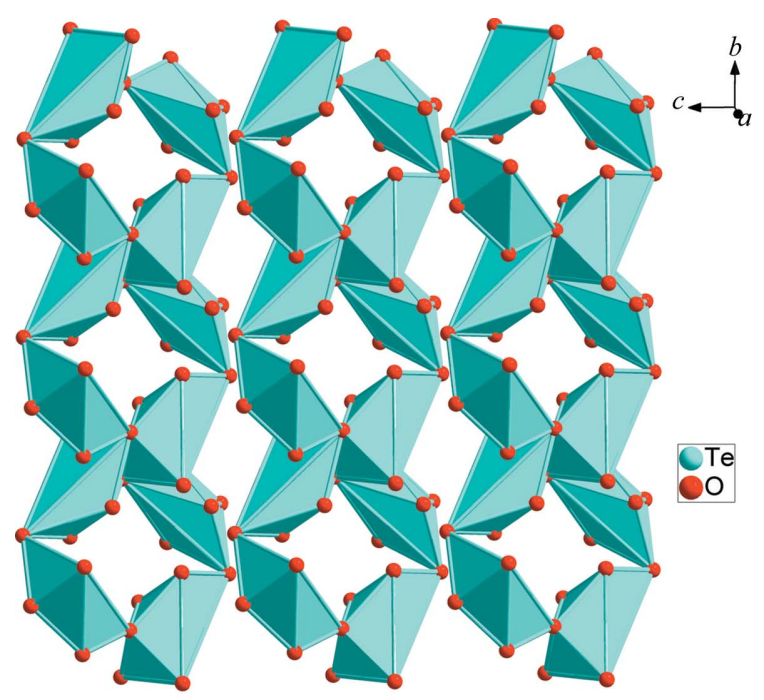

(a)

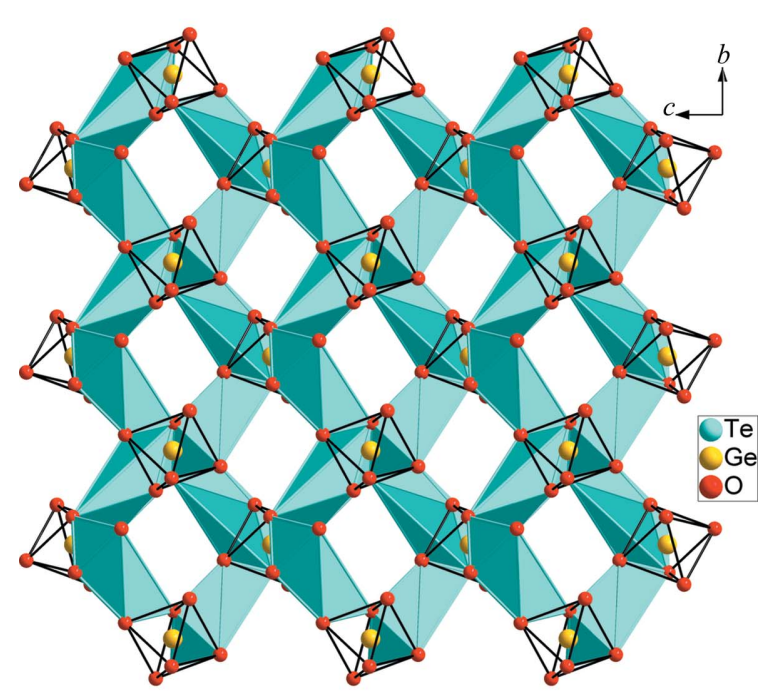

(b)

Figure 4

(a) A perspective view showing the double chains of $\mathrm{TeO}_{6}$ distorted octahedra. (b) A projection on to $y z$ showing the global structure of $\mathrm{GeTe}_{2} \mathrm{O}_{6}$ with the six-membered-ring channels. 


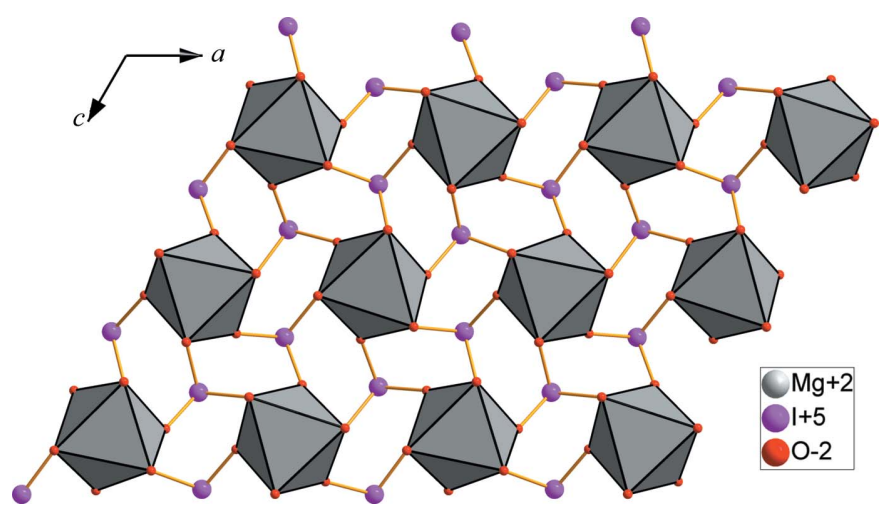

Figure 5

A projection on to the $x z$ plane of the $\mathrm{MgI}_{2} \mathrm{O}_{6}$ structure for comparison with $\mathrm{GeTe}_{2} \mathrm{O}_{6}$ (Fig. $3 a$ ).

octahedra, except $\mathrm{ZnTe}_{6} \mathrm{O}_{13}$. The other $M \mathrm{Te}_{2} \mathrm{O}_{6}$ tellurates adopt a structure type deriving from fluorite, suitable for tetravalent cations of greater size, such as $\mathrm{Ce}, \mathrm{Pu}$ and $\mathrm{Th}$ (Lopez et al., 1991; Krishnan et al., 2000).

The new $\mathrm{GeTe}_{2} \mathrm{O}_{6}$ type is structurally closer to the $M \mathrm{I}_{2} \mathrm{O}_{6}$ series of iodates $(\mathrm{V})$ with divalent cations $\mathrm{Mg}, \mathrm{Mn}, \mathrm{Co}, \mathrm{Ni}$ and $\mathrm{Zn}$ (Phanon et al., 2006). These $M \mathrm{I}_{2} \mathrm{O}_{6}$ compounds are isostructural and crystallize in the monoclinic system (space group $P 2_{1}$ ), but are very close to hexagonal symmetry $(\beta \simeq$ $\left.120^{\circ}\right)$. The general organization of the structures is similar, but $\mathrm{GeTe}_{2} \mathrm{O}_{6}$ is much more distant from ideal hexagonal symmetry than the $\mathrm{MI}_{2} \mathrm{O}_{6}$ series, as discussed above and as is easily observed by comparing Figs. 3(a) and 5. This higher distortion likely results from the smaller size of the $\mathrm{Ge}^{4+}$ cation $(R=$ $0.53 \AA$ ) compared with the size of the $M$ cations of the $M \mathrm{I}_{2} \mathrm{O}_{6}$ series (about $0.65-0.75 \AA$ ). This prevents the $\mathrm{TeO}_{3}$ polyhedra from adopting a nearly regular hexagonal framework and causes a tilting of the $\mathrm{GeO}_{6}$ octahedra.

\section{Experimental}

Small single crystals of $\mathrm{GeTe}_{2} \mathrm{O}_{6}$ were obtained accidentally in experiments initially intended to synthesize new oxyfluorotellurates(IV). $\mathrm{TeO}_{2}$ was prepared in the laboratory by decomposition at $823 \mathrm{~K}$ under flowing oxygen of commercial $\mathrm{H}_{6} \mathrm{TeO}_{6}$ (Aldrich, 99.9\%) and $\mathrm{GeO}_{2}$ was a commercial product (Aldrich, 99.9\%). An equimolar mixture of $\mathrm{GeO}_{2}$ and $\mathrm{TeO}_{2}$ was dissolved in hydrofluoric acid $(40 \%)$ in a Teflon beaker and heated at $453 \mathrm{~K}$. Then, after slow evaporation, the product was crushed and heated at $673 \mathrm{~K}$ in a platinum crimped tube for $48 \mathrm{~h}$. Small colorless tablets of $\mathrm{GeTe}_{2} \mathrm{O}_{6}$, air stable and suitable for structural study, were obtained instead of the expected germanium oxyfluorotellurate(IV).

\section{Crystal data \\ $\mathrm{GeTe}_{2} \mathrm{O}_{6}$ \\ $M_{r}=423.79$ \\ Monoclinic, $P 2_{1} / n$ \\ $a=5.2201(8) \AA$ \\ $b=6.9730(13) \AA$ \\ $c=7.3252(15) \AA$ \\ $\beta=91.66(2)^{\circ}$}

$$
\begin{aligned}
& V=266.52(8) \AA^{3} \\
& Z=2 \\
& \text { Mo } K \alpha \text { radiation } \\
& \mu=16.43 \mathrm{~mm}^{-1} \\
& T=293 \mathrm{~K} \\
& 0.02 \times 0.01 \times 0.003 \mathrm{~mm}
\end{aligned}
$$

Table 1

Selected bond lengths $(\AA)$.

\begin{tabular}{llll}
\hline $\mathrm{Te} 1-\mathrm{O} 3$ & $1.873(5)$ & $\mathrm{Te} 1-\mathrm{O}^{\mathrm{iii}}$ & $2.968(5)$ \\
$\mathrm{Te} 1-\mathrm{O} 2$ & $1.874(5)$ & $\mathrm{Ge} 1-\mathrm{O} 3$ & $1.870(5)$ \\
$\mathrm{Te} 1-\mathrm{O} 1$ & $1.903(5)$ & $\mathrm{Ge} 1-\mathrm{O} 1^{\mathrm{ii}}$ & $1.877(4)$ \\
$\mathrm{Te} 1-\mathrm{O} 1^{\mathrm{i}}$ & $2.852(5)$ & $\mathrm{Ge} 1-\mathrm{O}^{\text {iv }}$ & $1.878(5)$ \\
$\mathrm{Te} 1-\mathrm{O} 1^{\mathrm{ii}}$ & $2.877(5)$ & &
\end{tabular}

Symmetry codes: (i) $-x+1,-y,-z+1$; (ii) $x+\frac{1}{2},-y+\frac{1}{2}, z+\frac{1}{2}$; (iii) $-x+\frac{1}{2}, y-\frac{1}{2}$, $-z+\frac{3}{2}$; (iv) $x-\frac{1}{2},-y+\frac{1}{2}, z+\frac{1}{2}$.

Table 2

Bond valences $\left(v_{i j}\right)$ for $\mathrm{GeTe}_{2} \mathrm{O}_{6}$.

\begin{tabular}{llll}
\hline Atoms & $\mathrm{Te} 1$ & $\mathrm{Ge} 1$ & $v_{i j}$ \\
\hline O1 & $1.223 / 0.094 / 0.088$ & $2 \times 0.704$ & 2.11 \\
O2 & 1.321 & $2 \times 0.704$ & 2.03 \\
O3 & $1.326 / 0.069$ & $2 \times 0.719$ & 2.11 \\
$V_{i j}$ & 4.12 & 4.25 & \\
\hline
\end{tabular}

\section{Data collection}

Nonius KappaCCD diffractometer

Absorption correction: multi-scan (SADABS; Bruker 2001)

$T_{\min }=0.735, T_{\max }=0.952$

5004 measured reflections 771 independent reflections 551 reflections with $I>2 \sigma(I)$ $R_{\text {int }}=0.105$

\section{Refinement}

$R\left[F^{2}>2 \sigma\left(F^{2}\right)\right]=0.043$

$w R\left(F^{2}\right)=0.055$

$S=1.05$

771 reflections
44 parameters
$\Delta \rho_{\max }=2.24 \mathrm{e}^{-3}$
$\Delta \rho_{\min }=-1.72 \mathrm{e}^{-3}$
Data collection: KappaCCD Server Software (Nonius, 1998); cell refinement: DIRAX/LSQ (Duisenberg, 1992); data reduction: EVALCCD (Duisenberg et al., 2003); program(s) used to solve structure: SHELXS97 (Sheldrick, 2008); program(s) used to refine structure: SHELXL97 (Sheldrick, 2008); molecular graphics: DIAMOND (Brandenburg, 1999); software used to prepare material for publication: SHELXL97.

Supplementary data for this paper are available from the IUCr electronic archives (Reference: SQ3186). Services for accessing these data are described at the back of the journal.

\section{References}

Brandenburg, K. (1999). DIAMOND. Crystal Impact GbR, Bonn, Germany. Brown, I. D. (1981). Structure and Bonding in Crystals, Vol. 2, edited by M. O'Keeffe \& A. Navrotsky, pp. 1-30. New York: Academic Press.

Bruker (2001). SADABS. Bruker AXS Inc., Madison, Wisconsin, USA.

Cascales, C., Gutiérrez-Puebla, E., Monge, M. A. \& Ruíz-Valero, C. (1998). Angew. Chem. Int. Ed. 37, 129-131.

Duisenberg, A. J. M. (1992). J. Appl. Cryst. 25, 92-96.

Duisenberg, A. J. M., Kroon-Batenburg, L. M. J. \& Schreurs, A. M. M. (2003). J. Appl. Cryst. 36, 220-229.

FIZ/NIST (2008). Inorganic Crystal Structure Database. Version 1.4.5. Fachinformationszentrum Karlsruhe, Germany, and National Institute of Standards and Technology, Gaithersburg, MD, USA.

Gospodinov, G. (1999). Private communication to the PDF-4+ Database 2008. International Centre for Diffraction Data, Newton Square, Pennsylvania, USA.

Krishnan, K., Mudher, K. D. S. \& Venugopal, V. (2000). J. Alloys Compd, 307, 114-118.

Laval, J. P., Jennene Boukharrata, N. \& Thomas, P. (2008). Acta Cryst. C64, i12-i14. 


\section{inorganic compounds}

Liu, Y., Yang, X. L., Zhang, J., Li, Y. Z., Song, Y., Du, H. B. \& You, X. Z. (2008). Chem. Commun. pp. 3145-3147.

Lopez, M. L., Veiga, M. L., Jerez, A. \& Pico, C. (1991). J. Less Common Met. 175, 235-241.

Monge, M. A., Gutiérrez-Puebla, E., Cascales, C. \& Campá, J. A. (2000). Chem. Mater. 12, 1926-1930.
Nonius (1998). COLLECT. Nonius BV, Delft, The Netherlands.

Phanon, D., Bentria, B., Jeanneau, E., Benbertal, D., Mosset, A. \& GautierLuneau, I. (2006). Z. Kristallogr. 221, 635-642.

Sheldrick, G. M. (2008). Acta Cryst. A64, 112-122.

Xu, Y., Ogura, M. \& Okubo, T. (2004). Microporous Mesoporous Mater. 70, $1-6$. 